\title{
A new species of Argyreia (Convolvulaceae) from the southern Western Ghats, Tamil Nadu, India
}

\author{
Shalini S. ${ }^{1}$, Sujana K.A. ${ }^{2}$, Arisdason W. ${ }^{2}$ \& D. Maity ${ }^{3 *}$ \\ ${ }^{1}$ Central National Herbarium, Botanical Survey of India, Howrah, West Bengal - 711 103, India. \\ 2Botanical Survey of India, Southern Regional Centre, TNAU Campus, Lawley Road, Coimbatore, Tamil Nadu - 641 003 , India. \\ ${ }^{3}$ Department of Botany, University of Calcutta, 35, Ballygunge Circular Road, Kolkata, West Bengal - 700 019, India. \\ E-mail: debmaity@yahoo.com
}

\begin{abstract}
Argyreia lakshminarasimhanii S.Shalini, Sujana, Arisdason \& D.Maity a new species of Convolvulaceae from the southern Western Ghats of Tamil Nadu is described and illustrated here. The new species is morphologically different from its closely related species A. involucrata C.B.Clarke especially in its habit, shape, apex and texture of leaves, attachment of the stamens and in the length of the filaments. The micromorphological features of pollen grains are provided.
\end{abstract}

Keywords: Argyreia lakshminarasimhanii, Climber, Megamalai, Pollen morphology, Taxonomy.

\section{Introduction}

Argyreia Lour. (Convolvulaceae) comprises c. 140 species and is distributed predominantly in the tropics of Asia (Staples \& Traiperm, 2017; Traiperm \& Suddee, 2020), except for four species with disjunct distribution in Madagascar (Deroin, 2001). The genus is represented by 44 species and 3 varieties in India (Shalini et al., 2017) and the country can therefore be considered to be one of its centres of diversity. In India, especially the Western Ghats in Kerala and Tamil Nadu, accounts for the discovery of a number of new species and distributional records in Argyreia. The occurrence of a high degree of morphological polymorphism in Argyreia has generally led to misidentification of species in the past. Many species that are confined to Peninsular India of a number of complex groups

Received: 16.08.2020; Revised \& Accepted: 12.12.2020

Published Online: 31.12.2020 could possibly be described as new, if circumscription of every species in a complex group is carried out carefully.

During revisionary studies on the genus Argyreia in India, a few specimens were collected from the foothills of Megamalai (High Wavy Mountains) in Theni district of Tamil Nadu during July and September 2018. Critical study of the relevant literature (Clarke, 1883; Cooke, 1908; Gamble, 1922), and comparison with specimens and digital images of closely allied species, A. involucrata C.B.Clarke deposited in Indian (BSI, CAL, MH) and foreign herbaria (BM, E, K, P) revealed that the specimens of the present collections are clearly distinct from hitherto hence described here as a new species, with detailed description, illustration, and information on flowering and distribution. In addition, the pollen morphology of the new species and $A$. involucrata is compared (Fig. 3). The new species also shows similarity with $A$. boseana Santapau \& V.Patel and $A$. bracteata Choisy by their foliaceous bracts. A comparison of morphological characters between the new species and its closely allied species is provided in Table 1.

Argyreia lakshminarasimhanii S.Shalini, Sujana, Arisdason \& D.Maity, sp. nov.

Figs. $1 \& 2$

This new species most closely resembles $A$. involucrata C.B.Clarke in leaf shape (ovate, longer than broad), subcapitate cymes, large bracts but can easily be distinguished from the latter by densely tomentose abaxial leaf surface, retuse leaf apex, and short stamens, adnate to basal part of corolla tube. 

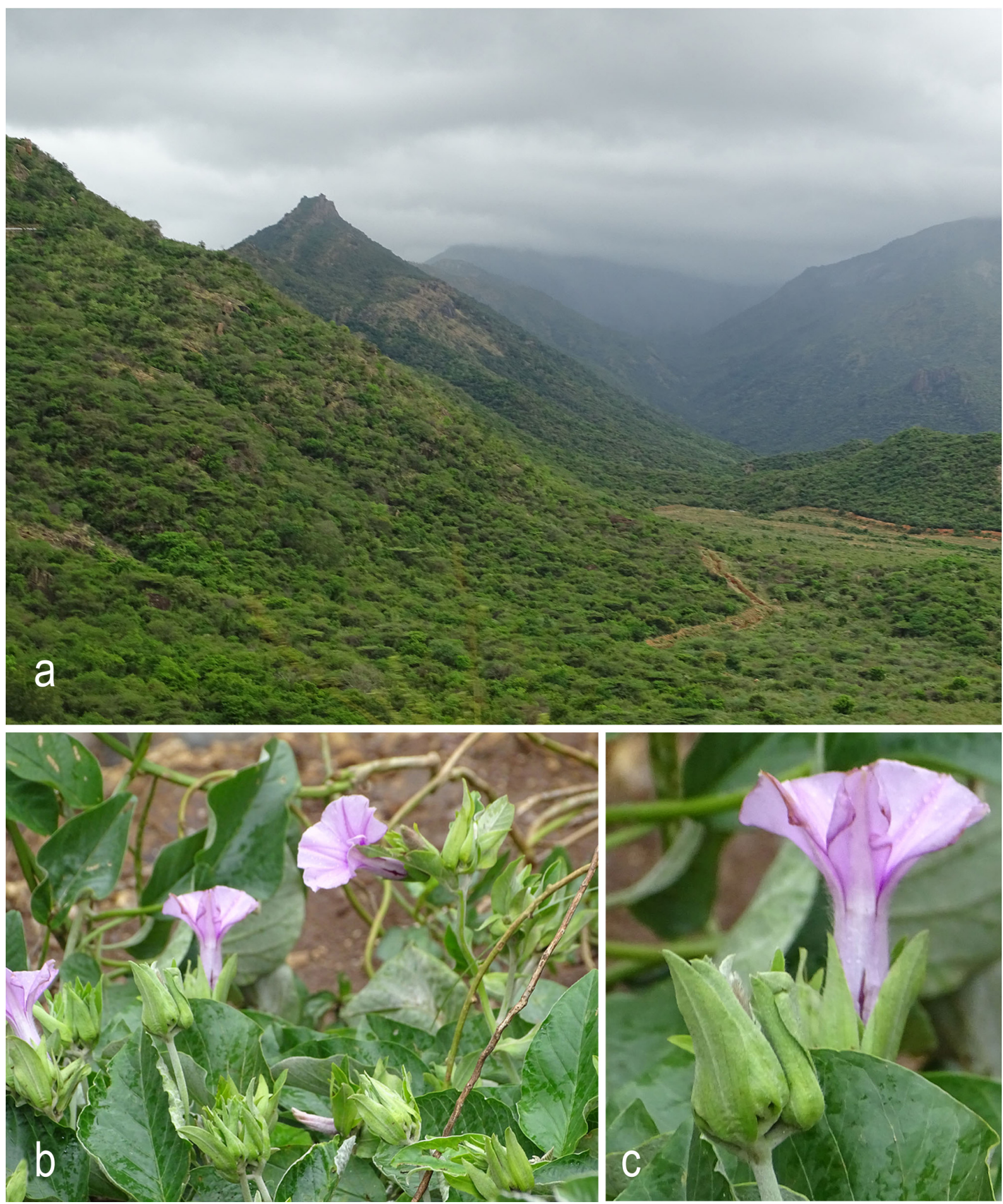

Fig. 1. Argyreia lakshminarasimhanii S.Shalini, Sujana, Arisdason \& D.Maity: a. Habitat; b. Habit (part); c. Flower (photos by K.A. Sujana).

Type: INDIA, Tamil Nadu, Theni district, foothill of Megamalai, on the ghat road, $\mathrm{N} 9^{\circ} 43-34 ", \mathrm{E}$ 77²5'11", $999.5 \mathrm{~m}, 11.07 .2018$, K.A. Sujana \& $S$. Shalini 70527 (holo CAL!; iso MH!, CUH!).

Woody, robust climber. Stems hollow, terete, white tomentose. Leaves ovate, elliptic-ovate or ovatelanceolate, 7-10.6 × 4.8-6 cm, obtuse or rounded or sometimes truncate at base, entire along margins, shortly obtuse, blunt or retuse at apex, leathery, adaxial surface glabrous, brownish green, abaxial 


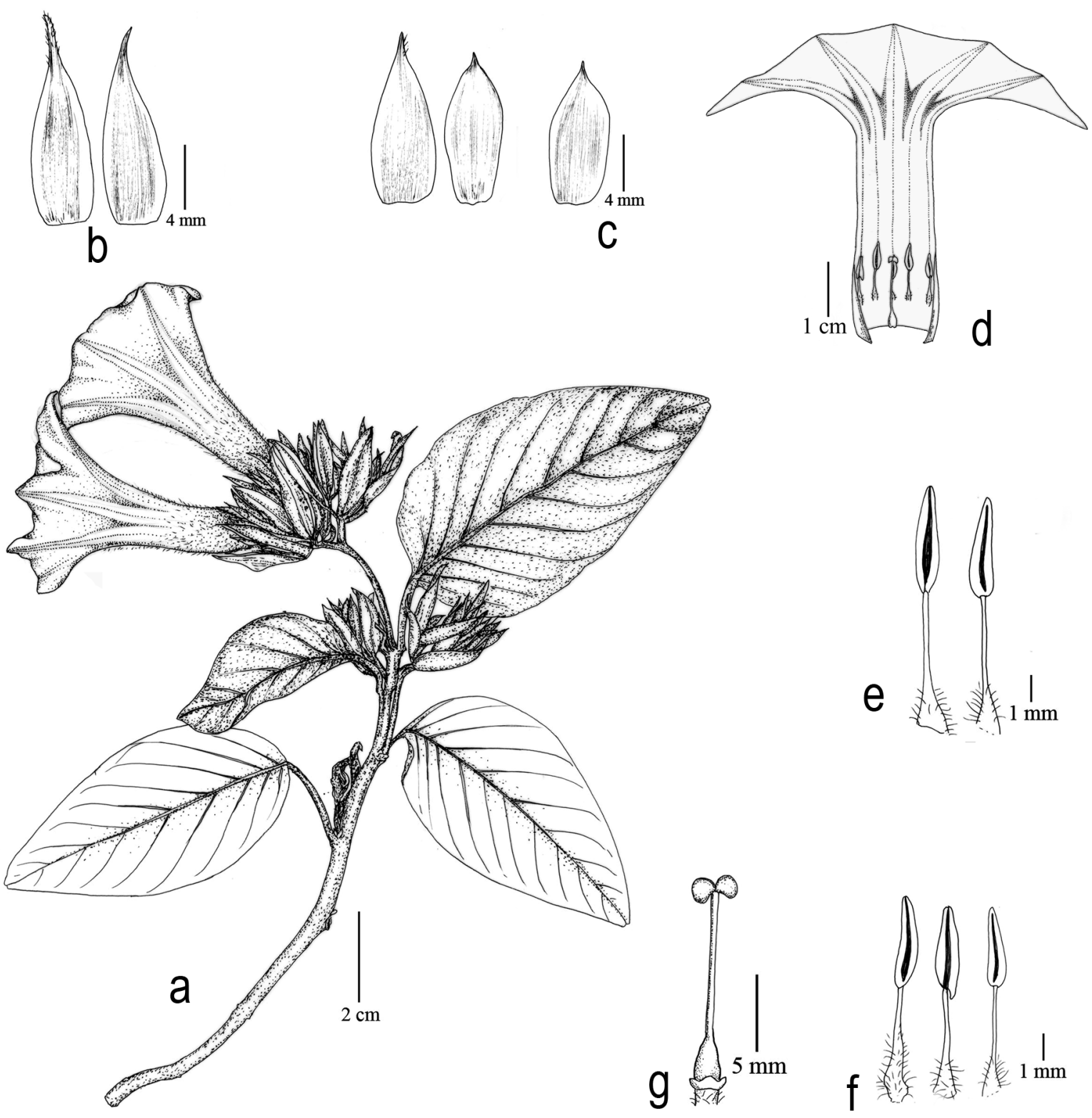

Fig. 2. Argyreia lakshminarasimhanii S.Shalini, Sujana, Arisdason \& D.Maity: a. Flowering branch; b. Outer sepals; c. Middle and inner sepals; d. Corolla split-open; e. Longer stamens; f. Shorter stamens; g. Gynoecium (from K.A. Sujana \& S. Shalini 70527; a-c and e-g drawn by D.K. Sah, and $\mathbf{d}$ by M. Midday).

surface densely white-tomentose; midrib and lateral veins conspicuous on both surfaces but more prominent and raised on abaxial surface, canaliculate above, thick towards base, densely tomentose; lateral veins 9-11 pairs; petioles terete, stout, $2-3.5 \mathrm{~cm}$ long, curved and swollen at base, densely tomentose. Inflorescence axillary, densely sub-capitate cymes, 10-12-flowered; peduncles stout, terete, equaling the petioles or exceeding, 2-7 cm long, densely tomentose. Bracts foliaceous, green; outer bracts elliptic or elliptic-lanceolate, $2.5-4 \times 0.5-1 \mathrm{~cm}$, tapering at base, obtuse or retuse at apex, 6-veined, glabrous inside, white-tomentose outside; inner bracts longer, narrower, ellipticoblong or linear-oblong, $1.5-3 \times 0.3-0.8 \mathrm{~cm}$, acute with a short mucro at apex, 5-veined, densely white tomentose outside, glabrous inside; pedicels 2-3 $\mathrm{mm}$ long, densely tomentose. Sepals 5 , unequal; outer 2 ovate, $11.5-13 \times 3.8-4 \mathrm{~mm}$, with thick long acuminate, sometimes slightly curved at apex, 

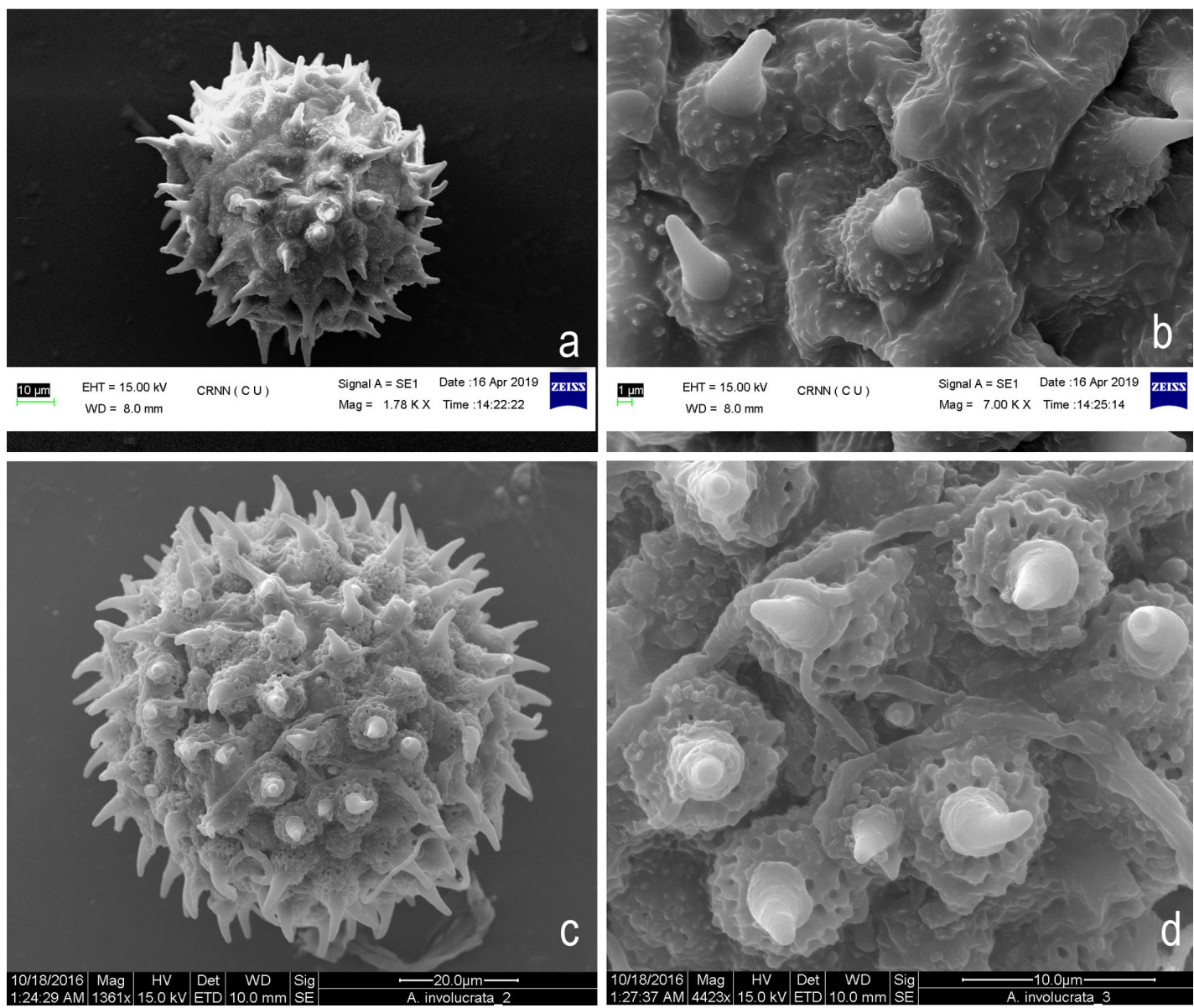

Fig. 3. SEM micrographs of pollen grains: a \& b. Argyreia lakshminarasimhanii S.Shalini, Sujana, Arisdason \& D.Maity: a. Entire pollen grain; b. Close-up of exine ornamentation; c \& d. A. involucrata C.B.Clarke: c. Entire pollen grain; d. Close-up of exine ornamentation.
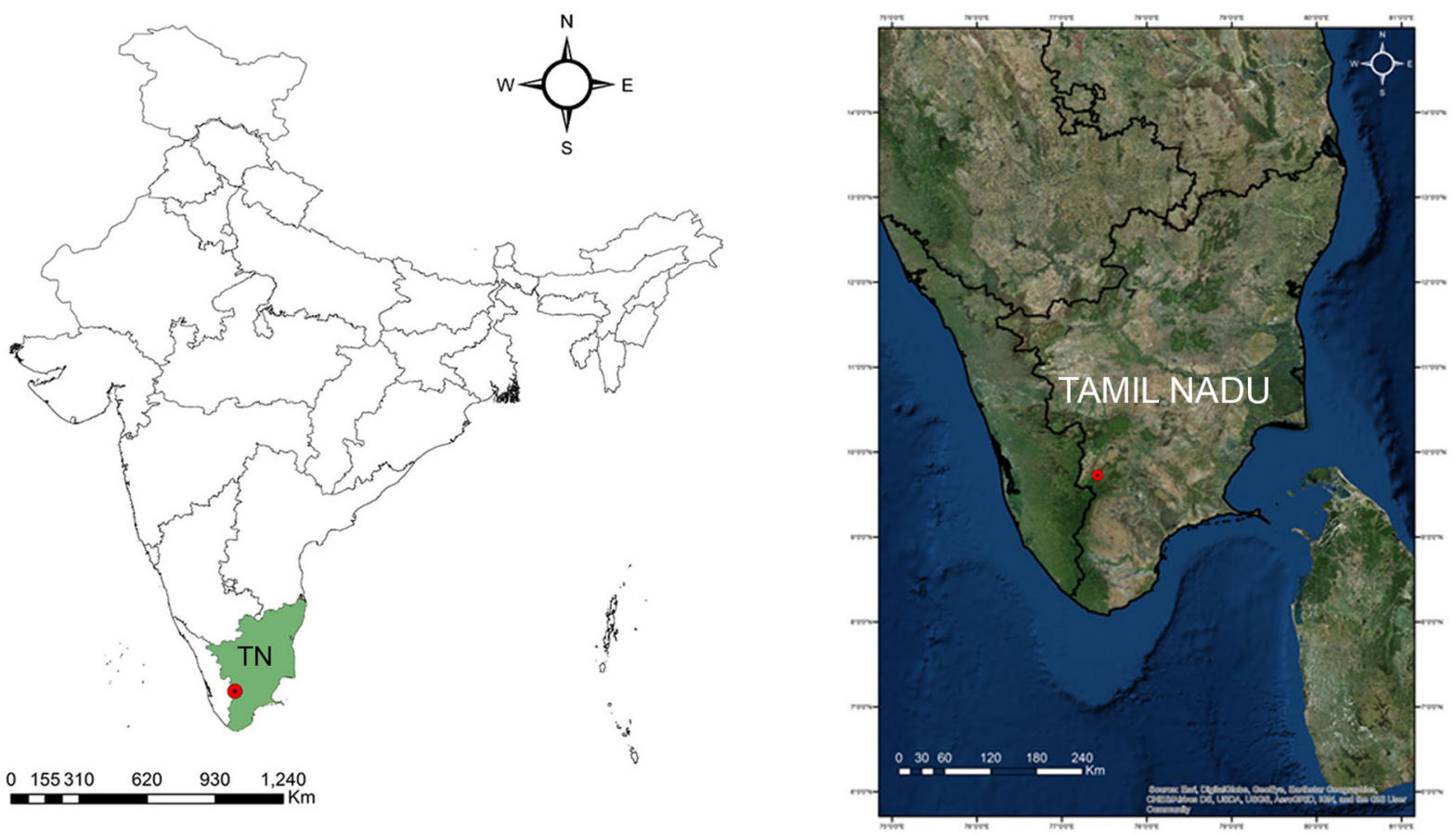

Fig. 4. Distribution of Argyreia lakshminarasimhanii S.Shalini, Sujana, Arisdason \& D.Maity (red dot indicates type locality) [drawn using the software ArcGIS 10.5]. 
slightly scarious at margins; middle one ovate, c. $10.8 \times 4.8-5 \mathrm{~mm}$, with thick short acuminate at apex, scarious on one margin, hairy outside only on exposed portion except on scarious margin; inner 2 ovate or ovate-oblong 9-10 × 3.5-4 mm, with a sharp mucro at apex, hairy on midrib outside, glabrous inside in all sepals. Corolla infundibular, 5-5.5 cm long, pink, midpetaline bands with white trichomes, mouth slightly lobed; tube $c .4 \mathrm{~cm}$ long, hairy outside. Disk annular, c. $2 \times 1 \mathrm{~mm}$, slightly lobed. Stamens 5, included, adnate at 3-5 mm above the base of corolla tube; filaments unequal, longer two, 4-5 mm, shorter three 3-4 mm, glandular indumentum and dilated at base; anthers oblong, 3-4 mm long. Pollen grains pantoporate, oblatespherical; exine spinous, bulbose bases of spines with minute tubercles (Fig. 3a \& b). Ovary conical, 1$2 \times$ c. $0.5 \mathrm{~mm}$, glabrous; style inserted, $0.8-1 \mathrm{~cm}$ long, glabrous; stigma bi-globose. Fruits not seen.
Flowering \& fruiting: Flowering from July to September; fruiting is not observed.

Habitat: Semi-evergreen and moist deciduous forests at an elevation of about $1000 \mathrm{~m}$.

Etymology: The species epithet refers to Dr. P. Lakshminarasimhan, former senior scientist of Botanical Survey of India and research supervisor of the first author, for his significant contributions to Indian taxonomy.

Distribution: Presently known only from the type locality, Megamalai, Theni district, Tamil Nadu, southern India, possibly endemic (Fig. 4). Found climbing on trees along the ghat roads on the way to the entrance of Megamalai Wildlife Sanctuary.

Specimens examined: INDIA, Tamil Nadu, Theni district, foothill of Megamalai, N 9 ${ }^{\circ} 43^{\prime} 43^{\prime \prime} \mathrm{E}$ 77²5’11", 999.5 m, 12.07.2018, K.A. Sujana \& $S$.

Table 1. Comparison of morphological characters between A. lakshminarasimhanii and its closely allied species.

\begin{tabular}{|c|c|c|c|c|c|}
\hline \multicolumn{2}{|c|}{ Characters } & $\begin{array}{l}\text { A. boseana Santapau } \\
\text { \& V.Patel }\end{array}$ & A. bracteata Choisy & $\begin{array}{l}\text { A. involucrata } \\
\text { C.B.Clarke }\end{array}$ & $\begin{array}{l}\text { A. lakshminarasimhanii, } \\
\text { S.Shalini, Sujana, } \\
\text { Arisdason \& D.Maity }\end{array}$ \\
\hline \multicolumn{2}{|c|}{ Leaf shape } & $\begin{array}{l}\text { Ovate to orbicular } \\
\text { (broader than long) }\end{array}$ & $\begin{array}{l}\text { Ovate to broadly ovate, } \\
\text { sometimes broadly } \\
\text { cordate-ovate }\end{array}$ & $\begin{array}{l}\text { Cordate-ovate or } \\
\text { broadly ovate, or } \\
\text { elongate-ovate } \\
\text { (longer than broad), } \\
\text { rarely ovate-lanceolate }\end{array}$ & $\begin{array}{l}\text { Ovate, elliptic-ovate } \\
\text { or ovate-lanceolate }\end{array}$ \\
\hline \multicolumn{2}{|c|}{ Leaf apex } & $\begin{array}{l}\text { Acute, acuminate } \\
\text { or apiculate }\end{array}$ & $\begin{array}{l}\text { Acute-retuse or } \\
\text { emarginated }\end{array}$ & Acute or acuminate & $\begin{array}{l}\text { Shortly obtuse, blunt } \\
\text { or retuse }\end{array}$ \\
\hline \multicolumn{2}{|l|}{ Leaf base } & Cordate to truncate & $\begin{array}{l}\text { Deeply to shallowly } \\
\text { cordate }\end{array}$ & Cordate or rounded & Rounded or truncate \\
\hline \multicolumn{2}{|c|}{ Leaf adaxial surface } & Glabrous & $\begin{array}{l}\text { Sparingly hairy } \\
\text { to glabrous }\end{array}$ & Strigose to glabrous & Glabrous \\
\hline \multicolumn{2}{|c|}{ Leaf abaxial surface } & $\begin{array}{l}\text { Sparingly hairy to } \\
\text { glabrous }\end{array}$ & Silky-sericeous & $\begin{array}{l}\text { Sparingly hairy to } \\
\text { sericeous }\end{array}$ & $\begin{array}{l}\text { Densely white- } \\
\text { tomentose, } \\
\text { not shining }\end{array}$ \\
\hline \multirow[t]{3}{*}{ Sepals } & Size & Unequal & Subequal & Unequal & Subequal \\
\hline & Apex & Acuminate & Acute & Caudate & $\begin{array}{l}\text { With a thick } \\
\text { long acuminate }\end{array}$ \\
\hline & $\begin{array}{l}\text { Outer } \\
\text { sepals }\end{array}$ & $\begin{array}{l}\text { Outer two abruptly } \\
\text { long acuminate }\end{array}$ & Outer two acute & $\begin{array}{l}\text { Outer two long- } \\
\text { caudate }\end{array}$ & $\begin{array}{l}\text { Outer two abruptly } \\
\text { short acuminate }\end{array}$ \\
\hline \multirow[t]{2}{*}{ Stamens } & $\begin{array}{l}\text { Adnation } \\
\text { (attachment) }\end{array}$ & $\begin{array}{l}\text { Below the throat } \\
\text { of the corolla tube }\end{array}$ & $\begin{array}{l}\text { Below the throat of } \\
\text { the corolla tube }\end{array}$ & $\begin{array}{l}\text { At the throat of the } \\
\text { corolla tube }\end{array}$ & $\begin{array}{l}\text { Base of the corolla } \\
\text { tube }\end{array}$ \\
\hline & Length & $1-1.4 \mathrm{~cm}$ & $1.2-1.5 \mathrm{~cm}$ & $1-1.5 \mathrm{~cm}$ & $0.6-0.9 \mathrm{~cm}$ \\
\hline
\end{tabular}


Shalini 70531 (CAL); ibid., 21.09.2018, K.A. Sujana \& S. Shalini $70575(\mathrm{MH})$.

Notes: The adnation (attachment) of stamens at the base of the corolla tube is the most important diagnostic feature of this novel taxon. In all the known species of Argyreia in India, the stamens are always adnate to the corolla either at the throat or just below it, whereas in A. lakshminarasimhanii the stamens are very short and adnate to the basal part of the corolla tube. The pollen exine architecture in the new species is different from its closest relative A. involucrata. The swollen bases of the spines possess minute tubercles in A. lakshminarasimhanii whereas in $A$. involucrata the swollen bases of the spines possess perforated polygonal pits (Fig. 3c \& d). The complete absence of perforations in the exine wall immediately separates the new taxon from its closest relative. Furthermore, the leaves of the new species are leathery with glabrous upper surface while the leaves of $A$. bracteata and $A$. involucrata are not leathery but hairy to sparingly hairy on both surfaces and in $A$. boseana they are glabrous on both surfaces.

\section{Acknowledgements}

Authors are grateful to Dr. A.A. Mao, Director, Botanical Survey of India (BSI), Kolkata, Dr. V.P. Prasad, Scientist 'E' \& HoO (Retd.), Central National Herbarium, BSI, Howrah (CAL), Dr. C. Murugan, Scientist 'E' \& former HoO, BSI, Southern Regional Centre (SRC), Coimbatore, for facilities and encouragement. They thank Dr. Kanchi N. Gandhi, Sr. Nomenclatural Registrar, HUH, Cambridge, for his suggestion on specific epithet ending. The first author also extends her sincere gratitude to Dr. R. Saravanan, Botanist,
AJC Bose Indian Botanic Garden, BSI, Howrah and Dr. S. Arumugam, Botanical Assistant, BSI, SRC, for their help during the plant collection. The authors also thank the curators/in-charge of herbaria, BSI, $\mathrm{MH}, \mathrm{K}, \mathrm{BM}, \mathrm{E}$ and $\mathrm{P}$, for granting permission to consult the herbarium or images of specimens. The first author is thankful to Dr. V. Madhukar, Research Associate, CAL, for preparing the map and Mr. D.K. Sah, Artist, CAL, Mr. Mrinmoy Midday, University of Calcutta, for the line drawings and $\mathrm{Mr}$. V. Ramesh, Photographer, BSI, SRC, for photo plate. Authors appreciate the corrections and suggestions of the referees and Prof. S. Nampy, Executive Editor, Rheedea for the improvement of the manuscript.

\section{Literature Cited}

CLARKE C.B. 1883. Convolvulaceae. In: HOOKER J.D. (ed.), The Flora of British India. Volume 4. L. Reeve \& Co., London. pp. 179-228.

COOKE T. 1908. The flora of the Presidency of Bombay. Volume 2. Taylor \& Francis, London. pp. 222-261.

DEROIN T. 2001. Convolvulaceae. In: MORAT P. (ed.), Flore de Madagascar et des Comores 171: 11-287.

GAMBLE J.S. 1922. Flora of the Presidency of Madras. Volume 2(4). Adlard \& Son, London.

SHALINI S., LAKSHMINARASIMHAN P. \& D. MAITY 2017. A new combination and lectotypification in Argyreia (Convolvulaceae). Nelumbo 59(2): 145-148. https://doi.org/10.20324/nelumbo/v59/2017/120448

STAPLES G.W. \& P. TRAIPERM 2017. A nomenclatural review of Argyreia (Convolvulaceae). Taxon 66(2): 445-477. https://doi.org/10.12705/662.12.

TRAIPERM P. \& S. SUDDEE 2020. A new species of Argyreia (Convolvulaceae) from Thailand. PhytoKeys 149: 109-115. https://doi.org/10.3897/phytokeys. 149.50379 . 